\title{
Comparative Study of White and Black Sesame by Using Oxygen Glucose Deprivation on PC12 Cells
}

\author{
${ }^{1}$ Nirmala Jamarkattel-Pandit \\ ${ }^{1}$ School of Health and Allied Sciences, Pokhara University, Nepal
}

\begin{abstract}
Sesame (Sesamum indicum L.) is one of the most important oilseed crops in the world. It is not only a source of edible oil, but also widely used in baked goods and confectionery products. Sesame seed varies considerably in color, size, and texture of the seed coat. The most commonly used are of white and black sesame, having almost same pharmacological activity and contain almost same components. However, it is reported that the components, such as Se, Zn, Fe, Mg, sesamin, and vitamin E, are different between the white and the black coat sesame. Active components of sesame seeds has been reported as protective effects against neuronal damage induced by chemical hypoxia or hydrogen peroxide but there was no sufficient biological study of white sesame and black sesame. In present study, oxygen and glucose deprivation followed by reoxygenation (OGD-R) model, an in vitro model of cerebral ischemia/reperfusion was used to investigate the effects and comparative study of white sesame and black sesame on different cell lines. This result clearly demonstrated that crude extract of white sesame is superior than crude extract of black sesame and fractions of white sesame and black sesame protected PC12 cells from hypoxia-induced stress.
\end{abstract}

Keywords: Oxygen glucose deprivation, PC12 Cells, Ischemia model, Sesamum indicum L.

Corresponding address: Nirmala Jamarkattel-Pandit, PhD. School of Health and Allied Sciences,

E-mail: nirmalajk@hotmail.com

\section{INTRODUCTION}

Sesame (Sesamum indicum L.) is one of the most important oilseed crops (because of its high content of lipid) in the world. ${ }^{1}$ It is not only a source of edible oil, but also widely used in baked goods and confectionery products. It is also consumed as a nutritious food, beneficial to health in many countries. Many studies have been conducted to investigate the health-promoting effect of sesame. ${ }^{2}$ Sesame oil is highly stable to oxidation compared with other plant oils. The main sesame lignans, namely sesamin and sesamolin, which are found in sesame oil. ${ }^{3}$ A number of lipid souble antioxidants have been isolated from sesame seeds, including sesamin, sesaminol, and sesamolinol. ${ }^{4}$ These compounds in sesame oil are responsible for many of its unique chemical and physiological effects, such as antioxidant and antimutagenic activities. Lignans are found to reduce the incidence rates of breast and prostate cancer and reduce serum cholesterol levels. ${ }^{5,6}$ Sesamol and sesamolin exhibited powerful inhibitory effects on lipid peroxidation of liposomes in rat liver and kidney. ${ }^{7}$ Sesamol shows the strong antimutagenic activity in the Ames tester strains TA100 and TA102. ${ }^{8}$

Sesame seed varies considerably in color, size, and texture of the seed coat. The most commonly used are of white and black sesame, having almost same pharmacological activity and contain almost same components. However, it is reported that the components, such as $\mathrm{Se}, \mathrm{Zn}, \mathrm{Fe}, \mathrm{Mg}$, sesamin, and vitamin E, are different between the white and the black coat sesame and the mice lipid peroxidation is significantly decreased by black sesame seed rather than white seed. ${ }^{9-1 l}$ Pinoresinol, lariciresinol, hydroxymatairesinol and allohydroxymatairesinol were isolated from black sesame seed, has appreciable superoxide radical scavenging effect $^{12}$. Content of pinoresinol and lariciresinol are far more abundant in black sesame than in white sesame. ${ }^{13}$ However, there was no sufficient biological study of white sesame and black sesame.

Neuronal injury, which is induced by cerebral ischemia/ reperfusion, has been associated with depletion of cellular energy sources, release of excitatory amino acids, mitochondrial dysfunction, and excessive generation of free radicals, all of which are contributing factors to the oxidative damage. ${ }^{14,15}$ Oxidative stress, due to excessive formation of hydrogen peroxide and oxygen-derived free radicals, causes cell damage through chain reactions of membrane lipid peroxidation, and/or alterations in membrane fluidity. Antioxidants have potential to protect cells from oxidative damage and were found to decrease reactive oxygen speciesinduced brain damage produced in different experimental models, as well as after ischemic insults. ${ }^{16-19}$ It is reported that the sesamin and sesamolin, active components of sesame, has protective effects against neuronal damage induced by chemical hypoxia or hydrogen peroxide through interaction with a wide variety of targets, including antioxidative action and attenuating neuron damage. ${ }^{20}$

Therefore, oxygen and glucose deprivation followed by reoxygenation (OGD-R) model, an in vitro model of cerebral ischemia/reperfusion was used to investigate the effects and comparative study of white sesame and black sesame 
on PC12 cell. PC12 cells are subjected to an initial short phase of OGD-R. The initial phase of OGD mimics the lack of oxygen and glucose supply, while the prolonged phase of OGD-R reflects the reperfusion of oxygen and glucose supply to the injured cells. ${ }^{21}$

\section{MATERIALS AND METHOD}

\section{Chemicals and reagents}

Extraction and fractionation of Sesame seeds. White sesame seed $(4.7 \mathrm{~kg})$ and black sesame seed $(4.9 \mathrm{~kg})$ were ground and defatted with $\mathrm{n}$-hexane(10L x 4 times) to obtain defatted sesame flour respectively, which were then extracted with $10 \mathrm{~L}$ of $80 \%$ methanol to obtain a crude extract FS-O (230gm) and BBS-O (265gm) respectively. The crude extract FS-O and BBS-O, then treated separately to $\mathrm{C}-18$ silica gel column $(500 \mathrm{~g}, 9 \times 15 \mathrm{~cm})$ and eluted by water $(100 \%)$, water $/ \mathrm{MeOH}$ $(3: 1 \mathrm{v} / \mathrm{v})$, water/MeOH $(2: 2 \mathrm{v} / \mathrm{v})$, water/MeOH$(1: 3 \mathrm{v} / \mathrm{v})$ and $\mathrm{MeOH}(100 \%)$ to obtain five different subfraction of FS and five different subfraction of BBS respectively. The collected fraction was dried and store at $-20^{\circ} \mathrm{C}$ until use.

\section{Cell culture and Oxygen-glucose deprivation.}

PC12 cells were purchased from the Korea cell line bank, and maintained at $37^{\circ} \mathrm{C}$ in a humidified atmosphere containing $5 \% \mathrm{CO}_{2}$. Cells were seeded at a density 1.5 $\times 10^{7} / \mathrm{L}$ in Dulbecco's modified Eagle's Medium(DMEM, Sigma, USA), supplement with $10 \%$ heat-inactivated fetal bovine serum(FBS, Hyclone, USA), penicillin $\left(1 \times 10^{5} \mathrm{U} / \mathrm{L}\right)$, streptomycin $(100 \mathrm{mg} / \mathrm{L})$. Experiments were carried out $24 \mathrm{~h}$ after cells were seeded.

On the day of the experiment, the regular high glucose $\operatorname{DMEM}(4.5 \mathrm{mg} / \mathrm{ml})$ was removed and replaced with glucosefree DMEM. The cultures were then kept in the ischemic device $\left(95 \% \mathrm{~N}_{2}\right.$ and $5 \% \mathrm{CO}_{2}$ at $\left.37^{\circ} \mathrm{C}\right)$ for $4 \mathrm{hr}$. At the end of the OGD period, glucose $(4.5 \mathrm{mg} / \mathrm{ml})$ was added and the cultures were returned to normal conditions (reoxygenation) for an additional $24 \mathrm{hr}$. Control cultures were maintained in the incubator under normal conditions (normoxia). Different samples of FS and BBS were added into the culture before $30 \mathrm{~min}$ and during OGD treatment.

Hydrogen peroxide induced cell death. PC12 cells were plated in 96-well plates and grown for $24 \mathrm{hr}$ before addition of DMEM plus $200 \mu \mathrm{M} \mathrm{H}_{2} \mathrm{O}_{2}$, incubation for $24 \mathrm{hr}$ at $37^{\circ}$ C. Different samples of FS and BBS were added into the culture before $2 \mathrm{hr}$ and during $200 \mu \mathrm{M} \mathrm{H}_{2} \mathrm{O}_{2}$ treatment. The control culture was maintained in normal DMEM and put in the incubator under normal condition.

\section{Cell survival determination.}

Cell survival was evaluated by the ability to reduction of 2-(4, 5-dimethylthiazol-2-yl)-2, 5-diphenyltetrazolium bromide (MTT) to formazan. MTT was dissolved in DMEM, and added to the culture at final concentration of $0.5 \mathrm{mg} /$ $\mathrm{ml}$. After additional $2 \mathrm{~h}$ incubation at $37^{\circ} \mathrm{C}$, the media were carefully remove and $100 \mu 1 \mathrm{DMSO}$ was added to each well.
The optical density was measured on plate reader (SPECTRA max, USA) at $570 \mathrm{~nm}$. Results were expressed as percentage of normal control group.

\section{RESULT}

Effect of crude extract of white (FS-O) and black sesame (BBS-O) on PC12 cell against oxygen glucose deprivation followed by reoxygenation (OGD-R).

The survival of cells after treatment of different concentration of crude extract FS-O and BBS-O at 30min before and during $4 \mathrm{~h}$ OGD was shown in Fig 2. Survival of cells increased from $44.17 \pm 2.33 \%$ in OGD control to $49.93 \pm 1.145 \%$ and $58.85 \pm 0.65 \%$ in cell treated with FS-O $(1 \mu \mathrm{g} / \mathrm{ml}$ and $10 \mu \mathrm{g} /$ $\mathrm{ml})$, like wise $48.40 \pm 2.42 \%, 51.30 \pm 3.55 \%, 54.61 \pm 3.55$ $\%$ in cell treated with BBS-O $(0.1 \mu \mathrm{g} / \mathrm{ml}, 1 \mu \mathrm{g} / \mathrm{ml}$ and $10 \mu \mathrm{g} /$ $\mathrm{ml})$ and $63.50 \pm 1.103 \%$ in cell treaded with sesamin $(1 \mu \mathrm{M})$ respectively. Sesamin was used as a reference compound. However, the higher concentration of FS-O, BBS-O could not show protective effect on OGD induced cell death.

Effect of crude extract of FS and BBS on HT22 cell against (OGD-R) In order to characterize the differentiation of white and black sesame, OGD-R on HT22 cells were used. The effect of different fraction of white sesame and black sesame after OGD-R on HT22 cell was studied using MTT assay. The survival of cells after treatment of different concentration of crude extract FS-O and BBS-O at 30min before and during 4 h OGD was shown in Fig 3.

Survival of cells increased from $56.16 \pm 2.20 \%$ in OGD control to $62.40 \pm 4.757 \%, 65.59 \pm 3.048 \%, \quad$ and $71.08 \pm$ $3.919 \%$ in cell treated with FS-O $(0.1 \mu \mathrm{g} / \mathrm{ml}, 1 \mu \mathrm{g} / \mathrm{ml}$ and 10 $\mu \mathrm{g} / \mathrm{ml}$ ) respectively. Like wise $60.29 \pm 1.94 \%, 63.23 \pm 2.024$ $\%, 68.84 \pm 4.894 \%$ in cell treated with BBS-O $(0.1 \mu \mathrm{g} / \mathrm{ml}, 1$ $\mu \mathrm{g} / \mathrm{ml}$ and $10 \mu \mathrm{g} / \mathrm{ml}$ ) and $74.86 \pm 3.417 \%$ in cell treaded with sesamin $(1 \mu \mathrm{M})$ respectively. These results demonstrated clearly that curde extract of FS and BBS protected HT22 cells from hypoxia-induced stress and FS-O was found to be more active than BBS-O

Effect of different fraction of FS and BBS on PC12 cell against (OGD-R)

The survival of cells after treatment of different fractions of FS $(10 \mu \mathrm{g} / \mathrm{ml})$ and BBS $(10 \mu \mathrm{g} / \mathrm{ml})$ at $30 \mathrm{~min}$ before and during $4 \mathrm{~h}$ OGD was shown in table 1, (Fig 4,5).

Effect of different fraction of FS and BBS on PC12 cell against $\mathrm{H}_{2} \mathrm{O}_{2}$-induced cytotoxicity

The loss of cell viability was measured by the reduction of MTT activity. PC12 viability was greatly reduced when exposed to $\mathrm{H}_{2} \mathrm{O}_{2}$ and the cytotoxicity of $\mathrm{H}_{2} \mathrm{O}_{2}$ was concentration and time-dependent in MTT assay (data not shown). The survival rate of $\mathrm{PC} 12$ was about $60 \%$ when the cells were treated with $200 \mu \mathrm{M}$ of $\mathrm{H}_{2} \mathrm{O}_{2}$ for $24 \mathrm{~h}$. The viability of PC12 cells treated with different fractions of FS and BBS at $2 \mathrm{~h}$ before and during exposure of $\mathrm{H}_{2} \mathrm{O}_{2}(200 \mu \mathrm{M})$ were increased in a statistically significant manner (fig 6). 
Table 1: - Protective effect of differerent factions of white and black sesame on Oxygen glucose deprivation induced neuronal injury in HT22 cells.

\begin{tabular}{|l|l|l|}
\hline Group & Cell Viability (\%) & Increase\% \\
\hline Control & 100 & \\
\hline OGD-R & $56.60 \pm 1.24$ & -- \\
\hline FS-1 + OGD-R & $73.37 \pm 5.25$ & 29.62 \\
\hline FS-2 + OGD-R & $75.95 \pm 3.89$ & 34.18 \\
\hline FS-3 + OGD-R & $72.42 \pm 1.25$ & 27.95 \\
\hline FS-4 + OGD-R & $71.83 \pm 0.93$ & 26.90 \\
\hline FS-5 + OGD-R & $52.02 \pm 3.26$ & -- \\
\hline OGD-R & $61.98 \pm 0.87$ & \\
\hline BBS-1 + OGD-R & $76.82 \pm 1.80$ & 23.94 \\
\hline BBS-2 + OGD-R & $70.00 \pm 4.23$ & 12.93 \\
\hline BBS-3 + OGD-R & $76.58 \pm 4.02$ & 23.55 \\
\hline BBS-4 + OGD-R & $73.41 \pm 2.49$ & 22.44 \\
\hline BBS-5 + OGD-R & $36.78 \pm 2.19$ & -- \\
\hline
\end{tabular}

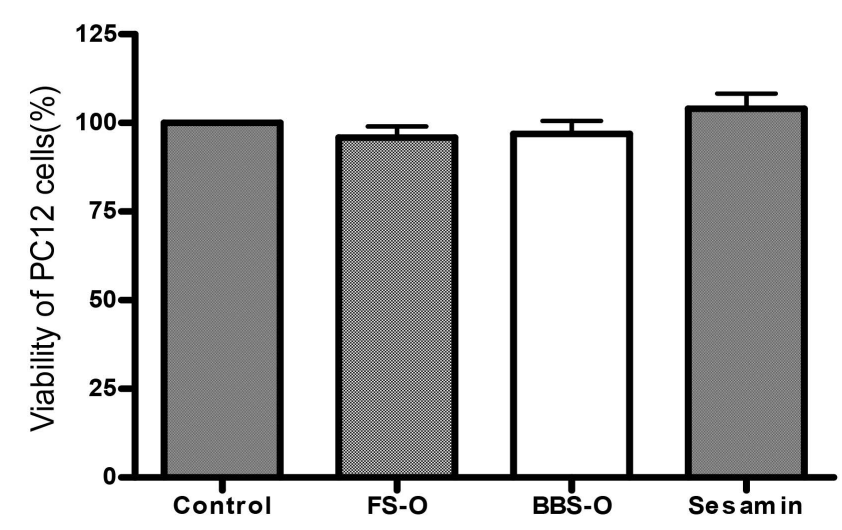

Figure 1: - Cytoprotective effect of crude extract of white and black sesame on PC12 cells.

Crude extract $(10 \mu \mathrm{g} / \mathrm{ml})$ and sesamin $(1 \mu \mathrm{M})$ were treated $24 \mathrm{~h}$ to the cells. The untreated group, as normal group was set to $100 \%$.

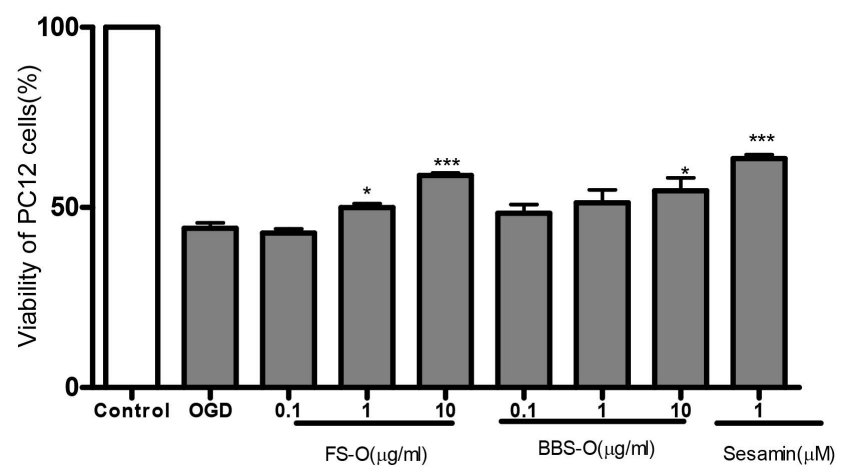

Figure 2: - Protective effect of crude extract of white and black sesame on Oxygen glucose deprivation induced neuronal injury in PC12 cells.

The PC12 cells were exposed to OGD $4 \mathrm{hr}$ following by 24 $\mathrm{hr}$ reoxygenation. Samples were pretreated to the cells before 30min and during OGD exposure. The OGD untreated group, as normal group was set to $100 \%$. The Value presents the mean (\%) \pm SEM. of each group. Significantly different from the OGD group $(* p<0.05, * * * p<0.005)$.

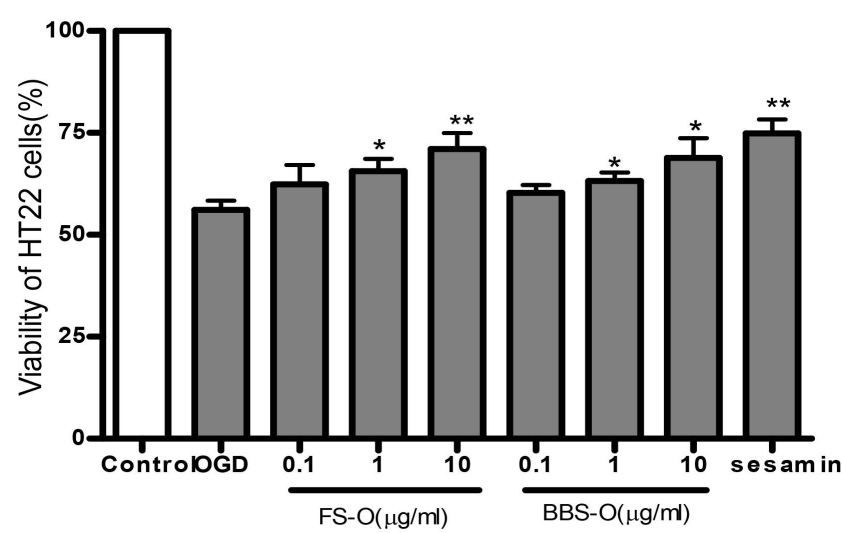

Figure 3: - Protective effect of crude extract of white and black sesame on Oxygen glucose deprivation induced neuronal injury in HT22 cells.

The HT22 cells were exposed to OGD $4 \mathrm{~h}$ following by 24 $\mathrm{h}$ reoxygenation. Samples were pretreated to the cells before $30 \mathrm{~min}$ and during OGD exposure. The OGD untreated group, as normal group was set to $100 \%$. The Value presents the mean $(\%) \pm$ SEM. of each group. Significantly different from the OGD group $(* p<0.05, * * p<0.01)$

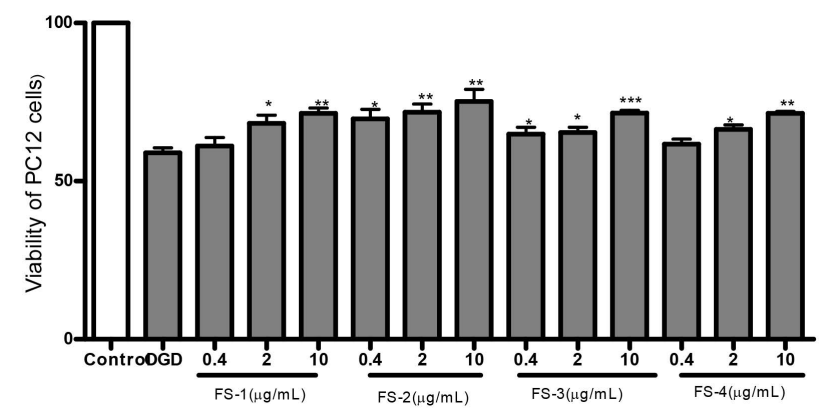

Figure 4: - Dose dependent effect of different fractions of white sesame on Oxygen glucose deprivation induced neuronal injury in PC12 cells.

The PC12 cells were exposed to OGD $4 \mathrm{hr}$ following by 24 $\mathrm{hr}$ reoxygenation. Samples were pretreated to the cells before $30 \mathrm{~min}$ and during OGD exposure. The OGD untreated group, as normal group was set to $100 \%$. The Value presents the mean $(\%) \pm$ SEM. of each group. Significantly different from the OGD group $(* p<0.05, * * * p<0.005)$.

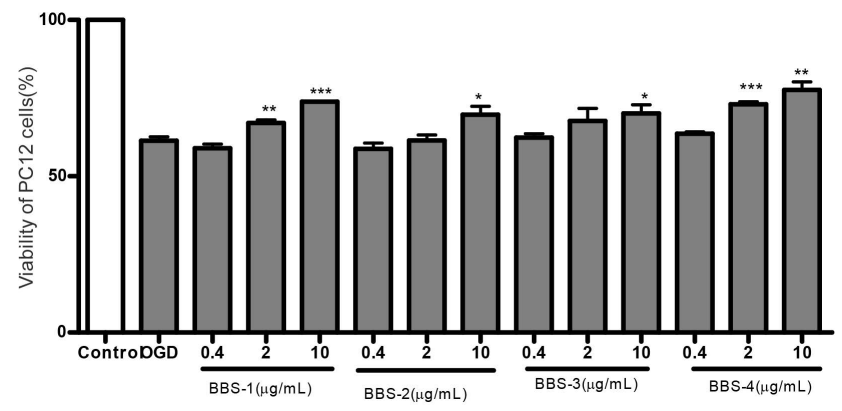

Figure 5: - Dose dependent effect of different fractions black sesame on Oxygen glucose deprivation induced neuronal injury in PC12 cells. 
The PC12 cells were exposed to OGD 4hr following by 24 $\mathrm{hr}$ reoxygenation. Samples were pretreated to the cells before $30 \mathrm{~min}$ and during OGD exposure. The OGD untreated group, as normal group was set to $100 \%$. The Value presents the mean $(\%) \pm$ SEM. of each group. Significantly different from the OGD group $\left(* p<0.05,{ }^{* * *} p<0.005\right)$.

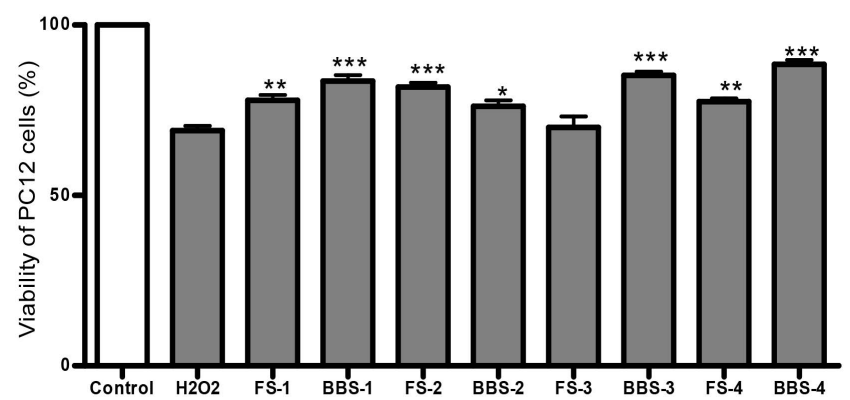

Figure 6: Protective effect of different fraction of white and black sesame on $\mathrm{H}_{2} \mathrm{O}_{2}$ induced neuronal injury in PC12 cells.

The PC12 cells were exposed to $\mathrm{H}_{2} \mathrm{O}_{2}(200 \mu \mathrm{m})$ for $24 \mathrm{~h}$. Samples were pretreated to the cells before $2 \mathrm{~h}$ and during $\mathrm{H}_{2} \mathrm{O}_{2}$ exposure. The $\mathrm{H}_{2} \mathrm{O}_{2}$ untreated group, as normal group was set to $100 \%$. The Value presents the mean $(\%) \pm$ SEM. of each group. Significantly different from the $\mathrm{H}_{2} \mathrm{O}_{2}$ group $(* p<0.05, * * * p<0.005)$.

\section{DISCUSSION}

In order to characterize the differentiation of white sesame (FS) and black sesame (BBS), OGD-R on PC12 cells and HT22 cells were used. The effect of different fraction of white and black sesame after OGD-R on PC12 cell and HT22 cells were studied using MTT assay. As determined by MTT reduction, such cells were very sensitive to OGD-R insult. OGD for $4 \mathrm{~h}$ and reoxygenation for $24 \mathrm{~h}$ induced death nearly $40 \sim 50 \%$ of cells as compare with normal control group. It is clearly demonstrated that crude extract of FS and BBS protected PC12 cells and HT22 cells from hypoxia induces cell death and FS was found to be more active than BBS. Different fractions of white sesame (FS-1, FS-2, FS-3 and FS-4) and black sesame (BBS-1 BBS-2, BBS-3 and BBS4) were all effective at protecting PC12 cells from hypoxic damage, among them FS-2 shows more protective activity where as BBS-5 and FS-5 could not protect the PC12 cell from hypoxic damage. In addition, FS-1, FS-2, FS-3 and FS-4 significantly enhanced the cell viability in dose dependent manner at higher concentrations. BBS-1, BBS-2, BBS-3, and BBS-4 also showed the dose dependent protection and the effect was particularly less effective than corresponding FS fractions. These results clearly demonstrated that fractions of white sesame and black sesame protected PC12 cells from hypoxia-induced stress.

\section{REFERENCE:}

1) Shyu YS, Hwang LS. Antioxidative activity of the crude extract of lignan glycosides from unroasted Burma black sesame meal. Food Research International, 2002; 35: 357-365.

2) Namiki M. The chemistry and physiological functions of sesame. Food Research International, 1995; 11: 281-329.

3) Corso MP, Klen MF, Silva EA, Filho LC, Santos JN, Freitas LS, Dariva C. Extraction of sesame seed (Sesamun indicum L.) oil using compressed propane and supercritical carbon dioxide. The Journal of Supercritical Fluids, 2010; 52: 56.

4) Fukuda Y, Nagate T, Osawa T, Namiki M. Contribution of lignan analogues to antioxidatvie activity of refined unroasted sesame seed oil. J. Am. Oil Chem. Soc, 1996; 63: 1027-1031.

5) Hirata F, Fujita K, Ishikura Y, Hosoda K, Ishikawa T, Nakamura H. Hypochoesterolemic lignan in human. Atherosclerosis, 1996; 122: 135-136.

6) Adlercreutz, H. Phyto-oestrogens and cancer. Lancet Oncol, 2002; 3: 364-373.

7) Kang MH, Naito M, Tsujihara N, Osawa T. Sesamolin inhibits lipid peroxidation in rat liver and kidney. J. Nutr, 1998; 128: 1018-1022.

8) Kaur PI, Saini A. Sesamol exhibits antimutagenic activity against oxygen species mediated mutagenicity. Mutat. Res, 2000; 470: 71-76.

9) Chen YH. Determination of mineral elements in white-coated and black-coated sesame seed. Microelem. Health Res, 1999; 16: 59-60.

10) Kang MH, Oh MK, Bang JK, Kim DH, Kang CH, Lee BH. Varietal difference of lignan contents and fatty acids composition in Korean sesame cultivars. Korean J. Crop Sci, 2000; 45: 203-206.

11) Ma YH, Wang Y, Wang HH. Effects of sesame and oat on blood-lipid and lipid peroxidation in growing mice. J. Chin. School Health, 1998; 19: 164-166.

12) Fukuda Y, Osawa T, Kawakishi S, Namiki M. Antioxidative activities of fractions of components of black sesame seeds. Nippon Shokuhin Kagaku Kogaku Kaishi, 1991; 38: 915-919.

13) Nagashima M, Fukuda Y, Ito R. Antioxidative lignans from industrial waste water in cleaning of black sesame seed. Nippon Shokuhin Kagaku Kogaku Kaishi, 1999; 46: 382-388.

14) Sims NR, Zaidan E. Biochemical changes associated with selective neuronal death following short-term cerebral 
ischaemia. The International Journal of Biochemistry and Cell Biology, 1995; 27: 531-550.

15) White BC, Sullivan JM, De Gracia DJ, O’Neil BJ, Neumar RW, Grossman LI, Rafols JA, Krause GS. Brain ischemia and reperfusion: molecular mechanisms of neuronal injury. Journal of Neurological Sciences, 2000; 179: 1-33.

16) Jelkmann W, Pagel H, Hellwig T, Fandrey J. Effects of antioxidant vitamins on renal and hepatic erythropoietin production. Kidney Int, 1997; 51: 497-501.

17) Clements JA, Saunders RD, Ho PP, Phebus LA, Panetta JA. The antioxidant LY231617 reduces global ischemic neuronal injury in rats. Stroke, 1993; 24: 716-723.

18) Watanabe T, Yuki S, Egawa M, Nishi H. Protective effects of MCI-186 on cerebral ischemia: possible involvement of free radical scavenging and antioxidant actions. J Pharmacol Exp Ther, 1994; 268: 1597-1604.

19) Zhong P, Raymond TFC. Melatonin protects SHSY5Y neuronal cells but no cultured astrocytes from ischemia due to oxygen and glucose deprivation. J. Pineal Res, 2003; 34: 194-201.

20) Rolis CH, Hsueh-Meei H, Jason TCT, Kee-Ching GJ. Protective Effects of Sesamin and Sesamolin on Hypoxic Neuronal and PC12 Cells. Journal of Neuroscience Research, 2003; 74: 123-133.

21) Tabakman RP, Lazarovici P, Kohen R. Neuroprotective effects of carnosine and homocarnosine on pheochromocytoma PC12 cells exposed to ischemia. J Neurosci Res, 2002; 68: 463-69. 